https://helda.helsinki.fi

\title{
The perfect - aspectual, temporal and evidential
}

\section{Lindstedt, Jouko}

De Gruyter Mouton

2000

Lindstedt, J 2000 , The perfect - aspectual, temporal and evidential . in Ö Dahl (ed.), Tense and aspect in the languages of Europe. Empirical Approaches to Language Typology, no. 20-6, De Gruyter Mouton, Berlin \& New York , pp. 365-383 .

http://hdl.handle.net/10138/33859

acceptedVersion

Downloaded from Helda, University of Helsinki institutional repository.

This is an electronic reprint of the original article.

This reprint may differ from the original in pagination and typographic detail.

Please cite the original version. 


\section{Tense and Aspect in the Languages of Europe}

edited by

Östen Dahl

Mouton de Gruyter

Berlin • New York 2000 



\section{The perfect - aspectual, temporal and evidential}

\section{Introduction}

The perfect has found its way from grammars of Classical Greek and Latin to those of modern European languages - as a term. But it is usually described as part of language-specific tense and aspect systems; there have not been many attempts to explore its nature as a cross-linguistic category, and it is often not even asked whether the "Perfects" of languages A and B are really manifestations of the same typological feature at all, or only happen to share the same name for obscure historical reasons.

The perfect and its development in various European languages was one of the focal research areas of the EUROTYP Tense and Aspect Theme Group. The point of departure was Dahl's (1985: 129-153) important result that a cross-linguistic category of perfect can be identified empirically, without a preconceived definition of its semantics. The perfects of various languages centre on certain prototypical examples like the following (Dahl 1985: 131); the uninflected verb should be replaced with a properly inflected verb form in each language under investigation:

[A says: I want to give your brother a book to read, but I don't know which. Is there any of these books that he READ already? - B answers:] (Yes,) he READ this book.

Obviously, the English Perfect (as in He has read this book, or He's read this one) would be a good candidate for an instance of this cross-linguistic gram type (for a definition of the term, see Dahl, this volume).

Material about the perfect and related categories was collected by means of a typological questionnaire, referred to as the Perfect Questionnaire - PFQ for short in the articles of this section (see Appendix 2). The first part contains 88 items, each consisting of one or more sentences to be translated with the help of contextual information (for translation questionnaires, see Dahl 1985, and Dahl, this volume); Part II, to be answered by a linguist, contains analytical questions. So far the questionnaire has been completed in over thirty languages, ${ }^{1}$ and for some of these, such as Dutch, Italian and Macedonian, as well as the Serbo-Croatian area, ${ }^{2}$ dialectal or individual variation has been taken into account to some extent.

Maslov (1990) gives the following notional definition of the perfect: "an aspectotemporal form of the verb, expressing a present state as a result of a preceding action or change, and/or expressing a past action, event or state that is somehow important 
to the present and is considered from the present point of view, detached from other past facts" (my translation). Actually the first part of the definition rather applies to a gram type called resultative (see below); important elements in the definition of the perfect proper are (1) the relevance of a past situation from the present point of view and (2) detachment from other past facts, i.e., non-narrativity. According to Comrie (1976: 52), "the perfect indicates the continuing present relevance of a past situation". The notion of current relevance (CR) is further explicated by Dahl and Hedin (this volume).

In their recent major work on the grammaticalization of tense, aspect and modality, Bybee, Perkins \& Pagliuca (1994) define the gram type anterior, which is essentially the same as the perfect discussed here. Their definition is, however, broader in that it also provides for past anteriors and future anteriors: "an anterior signals that the situation occurs prior to reference time and is relevant to the situation at reference time [...] Anteriors may occur with past or future tense marking" (p. 54). Past perfects (or pluperfects) and future perfects (futura exacta) share several properties with present perfects, but they also have some special uses and characteristics of their own, and they will not be discussed in this chapter, although PFQ does contain several items pertaining to them.

In PFQ, definitions have been operationalized: a language possesses a perfect if it has a gram, associated with the verb, that is used in most of the first seven examples-which illustrate different kinds of CR of past situations-but is not used in the following four examples, consisting of short narratives. ${ }^{3}$ This means that there is a negative criterion as well: the perfect is not a narrative tense, and therefore the Latin and Serbo-Croatian Perfects, for instance, do not belong to the cross-linguistic type "perfect" at all-the Latin Perfect is a perfective past tense, and the Serbo-Croatian Perfect is a general past tense, or preterite. ${ }^{4}$

In terms of Greenberg's (1978: 75-76) distinction between the stability and frequency of typological features, the perfect is a gram type that is frequent, that is to say, likely to appear in different languages, but unstable, as it often tends to be lost. More often than not, it does not disappear as a form but becomes something else - a general past tense, for instance.

\section{From resultative to current relevance}

Bybee and Dahl (1989: 67-68) list four typical diachronic sources of the perfect in the languages of the world: (i) copula + past participle of the main verb; (ii) possessive constructions involving a past participle of the main verb; (iii) main verb + particle meaning 'already'; (iv) constructions involving verbs like 'finish' or 'cast aside'. The two latter sources are by their semantics completive constructions, whereas the two first ones, common in European languages, are resultatives (Bybee, Perkins \& 
Pagliuca 1994: 53-74). A European perfect deriving from a possessive construction often involves a transitive verb meaning 'to have'; if this is the case, it can be called a 'have' perfect. ${ }^{5}$ A copula-based perfect is a 'be' perfect.

The distinction between resultatives and perfects has been established in linguistics only recently, largely owing to the important collective work edited by Nedjalkov (1988/1983). Resultatives "signal that a state exists as a result of a past action" (Bybee, Perkins \& Pagliuca 1994: 54). Traditionally the resultative is often subsumed under the category of perfect as a special "statal" variant (as in Maslov's definition quoted above), or it is simply called a "stative". For the criteria of distinguishing resultatives from perfects, the reader is referred to Nedjalkov \& Jaxontov (1988), Dahl (1985: 133-135), Bybee \& Dahl (1989: 68), and Bybee, Perkins \& Pagliuca (1994: 63-687), but the most important single difference should be mentioned here: only resultatives combine with adverbs of unlimited duration, such as 'still' or 'as before'. In English, it is not possible to say *She has still gone (if still is used in its temporal meaning)-compare with the resultative construction She is still gone.

In Finnish, the perfect and its resultative source coexist, but they are formally differentiated in the plural:

(2) Finnish

He o-vat väsy-nee-t.

they be-PRS:3PL become:tired-PP-PL:NOM

'They have become tired.'

(3) Finnish

He o-vat väsy-ne-itä.

they be-PRS:3PL become:tired-PP-PL:PRTV

'They are tired.'

$\left(2^{\prime}\right) \quad$ Finnish

*He o-vat yhä väsy-nee-t.

they be-PRS:3PL still become:tired-PP-PL:NOM

$\left(3^{\prime}\right) \quad$ Finnish

He o-vat yhä väsy-ne-itä.

they be-PRS:3PL still become:tired-PP-PL:PRTV

'They are still tired.'

The Finnish resultative construction, besides accepting an adverb meaning 'still', follows the syntactic rule of ascriptive ${ }^{6}$ sentences whereby the predicate adjective is usually in the partitive case when the subject is plural but does not refer to a pair of things; the perfect conserves a petrified older syntactic rule and puts the participle into the nominative. 
The perfect is typically a periphrastic gram, being formally close to its resultative (or completive) source. An important exception seems to be the old Indo-European Perfect, as attested in Classical Greek and Old Indic. A newer inflectional perfect in statu nascendi is the active resultative construction in North Russian dialects (Trubinskij 1988: 394; Tommola, this volume):

$$
\begin{aligned}
& \text { Russian (dialectal) } \\
& \text { On den'gi poluči-vši } \\
& \text { he money receive-PST:GER } \\
& \text { 'He has received the money.' }
\end{aligned}
$$

This resultative gram - which has already assumed some features of a real perfect, cf. Nedjalkov \& Jaxontov (1988: 42-43) - is not periphrastic for the simple reason that there is no present tense copula in Russian; in the past tense, the copula is regularly expressed in the resultative, too. It is possible that what look like inflectional perfects usually come into existence as copula-less ascriptive structures.

Semantically, the change from resultative into perfect means the generalization of meaning from "current result" to "current relevance". Lexically this is reflected in the spread of the gram from telic to atelic verbs (cf. Bybee, Perkins \& Pagliuca 1994: 68-69; Dahl \& Hedin, this volume). As the semantic connection between resultativity and CR is easy to grasp, the central use of the perfect is often called the "resultative perfect". But since the "still test" and similar criteria are operational in showing whether the transition from resultative proper to perfect has taken place, I shall speak rather of the "CR perfect" instead.

A CR perfect is a perfect in its most central, prototypical meaning. Is it a tense or an aspect category? In a gram-based approach this is not an essential question. Classifying the perfect among aspects or among tenses would not significantly add to our understanding of it. But if tenses express the temporal location of situations, and aspects their temporal shape, it can at least be said that the rise of a CR perfect is associated with the loosening of the aspectual properties of its resultative (or completive) source. As noted by Bybee (1985: 160), "it seems to resemble a tense more than an aspect, since it does not affect the internal temporal contours of the situation"? 7

The central aspectual parameter of boundedness comes in two varieties: when telic situations reach their natural end-points, we can speak of material bounds (as in Susan built a beautiful house); when a situation, not necessarily telic, is limited temporally, a temporal bound is reached (as in Susan slept for nine hours; see Lindstedt 1995; cf. also Bertinetto \& Delfitto, this volume). A material bound entails a temporal bound, but not vice versa. Resultativity presupposes a material bound, whereas CR only presupposes a temporal bound: a sentence like Someone has been here implicates that the presence of that someone has ceased, but it does not make "being here" a telic situation. 


\section{From current relevance to indefinite past}

The CR perfect shades into what is usually called the experiential (or existential) perfect. In English, these two types are formally differentiated only in rare cases like the following (cf. Comrie 1976: 58-59):

$$
\text { Mary has gone to Paris. }
$$

Mary has been to Paris.

In (5), the fact of Mary's having gone to Paris may be relevant to the present state of affairs in various ways, but typically the sentence implicates at least that she is not present. The experiential perfect of (6) only expresses that the past situation in which Mary went to Paris is more indirectly part of the present state of affairs, most notably through Mary, who perhaps now knows what Paris is like.

In its narrower definition, an experiential perfect presupposes an animate agent, since it expresses that "certain qualities or knowledge are attributable to the agent due to past experiences" (Bybee, Perkins \& Pagliuca 1994: 62). In a broader definition, it only means that "a given situation has held at least once during some time in the past leading up to the present" (Comrie 1976: 58). This notion is further explicated by Dahl \& Hedin (this volume), who call it "type-focusing event reference" (as opposed to "token-focusing event reference", as in Mary went to Paris).

The experiential perfect is a way of referring to a past situation without referring to a particular occasion, that is to say, it is characterized by non-specific past time reference. From this point of view, it is more tense-like than the CR perfect, being an indefinite past tense which typically occurs in questions and negated assertions with 'ever'-type adverbials. However, CR and experientiality do not exclude each other; in examples like (1), elements of both can be discerned.

This gradual transition of the perfect from the aspectual to the temporal domain means that it comes to be linked to an integrative way of viewing the past (Lindstedt 1983). The narrative tenses - the tenses of Weinrich's (1963) erzählte Welt - primarily refer to specific occasions, to the past moments defined by the internal structure of each narrative. If all possible past occasions are spoken about, the dynamic worlds of narratives must be replaced by a single static world, Weinrich's besprochene Welt, comprising the past, present and future. In the perfect's world, all past situations are still present - first through their results, then because they themselves become parts of this "extended now" (cf. McCoard 1978).

However, experientiality as such is neither a necessary nor a sufficient condition for a gram to be called a perfect. Experientials proper are a distinct gram-type, described by Dahl (1985: 139-144); the Japanese -ta koto ga aru is a well-known example (see also Dahl \& Hedin, this volume). 
In Slavic languages without a distinct perfect gram, the CR perfects of other languages are usually rendered with Perfective Past forms, whereas experiential perfects can often be translated with Imperfective Pasts. In Bulgarian, which does possess a perfect, a Perfect of a Perfective verb is interpreted as a CR perfect, whereas experiential Perfects are usually Imperfective (see Lindstedt 1985: 223-229; Lindstedt 1995: 99-100). Compare:

Bulgarian

A vie kăde ste ču-l-i tova?

but you:PL where be:2PL hear:PFV-PP-PL that:NT

'Where did you [polite] hear that?' (CR perfect)

An evasive answer would be:

$$
\begin{array}{ll}
\text { Bulgarian } & \\
\text { Ču-va-l-a } & \text { săm. } \\
\text { hear-IPFV-PP-F } & \text { be:1SG } \\
\text { 'I've just heard.' (experiential perfect) }
\end{array}
$$

Although the experiential meaning may become dominant in the perfect, historically it is usually secondary and derives from the CR meaning. The perfect of a particular language may well be compatible with specific past time adverbials. Sentence (9) is ungrammatical in English, to be sure:

(9) *I have woken up at 4 o'clock this morning.

However, a perfect would be possible - though not the only alternative - in Finnish and Bulgarian, for instance. This is because there is an obvious CR reading - I woke up so early that I am now tired. ${ }^{8}$ According to Dahl (1985: 137-138), Swedish seems to occupy an intermediary position: a specific time adverbial can combine with the perfect if it is in the information focus.

I assume that the degree of incompatibility of specific time adverbials with the perfect in a particular language shows to what extent it has become a dominantly experiential form and, therefore, a kind of tense. A possible next stage in this development would be the total loss of the CR reading, and this is what may be taking place in American English. If a child asks his or her parent, "Can I go now?", the counter-question (10a) strikes one as belonging to an American parent, whereas (10b) is the preferred alternative in British English (PFQ: 5):

(10) a. Did you do your homework?

b. Have you done your homework? 
I am not aware of any extensive studies of this difference, but its existence, as a tendency rather than a rule, is generally taken for granted. ${ }^{9}$ I assume that the experiential function has been preserved much better in American English than the CR function has; thus, both British and American speakers would normally ask, for instance, Have you (ever) met my sister?; the sentence Did you meet my sister? would refer to a specific occasion or interval. The American perfect can be considered to be more tense-like than its British counterpart.

To return to Bulgarian, at closer examination the situation in this language is similar to the American English situation in that CR does not require a Perfect form to be used at all; as a matter of fact, the Aorist could well be used in translating (10):

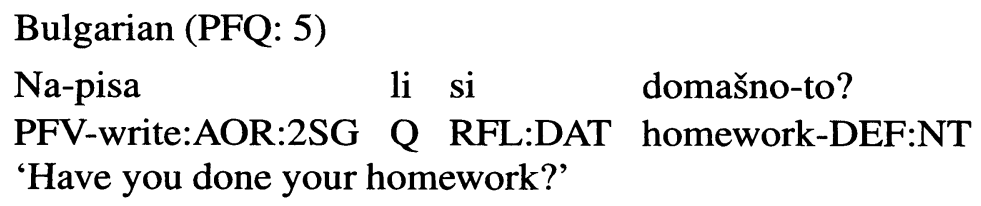

Although the Perfect would also be possible here, it is actually difficult to show that the Modern Bulgarian Perfect has a CR meaning because, as was mentioned, what look like CR perfects are always instances of the Perfective Aspect. As the CR meaning can be expressed with a Perfective Aorist, but not with an Imperfective Perfect, it must be the Perfective, not the Perfect, that is the primary carrier of the CR meaning. On the other hand, the Perfect is obligatory in experiential contexts, a fact which is also reflected in native grammarians' traditional name for this gram, minalo neopredeleno vreme 'past indefinite tense'.

Hannu Tommola and Nina Niissalo (p.c.) point out that the same situation is observed in Slavic as early as in Old East Slavic ("Old Russian") texts: experientiality requires the Perfect, but in the CR meaning, both Perfective Perfects and Perfective Aorists are possible. It is thus possible that the CR meaning of the Slavic Perfect grew weaker early in the Proto-Slavic period when verbal aspect came into being.

\section{The perfect becomes a narrative tense}

When a perfect can be used as a narrative tense (with the possible exception of evidential contexts, see below), it has ceased to be a perfect. This is what has happened in the majority of Slavic languages, as well as in South German and North Italian dialects, in Sardinian (Georg Bossong, p.c.) and spoken French. As a matter of fact, the perfect has become a peculiar "maritime category" in Modern Europe - most of the languages and dialects with a stable perfect are situated on the fringe of the continent: the Baltic Finnic languages, Scandinavian languages, North German dialects, English, Portuguese, Spanish, South Italian dialects, Greek, Albanian, Macedonian and Bulgarian. (Cf. Thieroff, this volume, Map 4.) 
The macroareal picture is completed by the observation that at the corners of this maritime fringe, Portuguese and Modern Greek exhibit what look like "young perfects", with relatively strong restrictions on what counts as CR. As can be seen in the article of Squartini \& Bertinetto (this volume), the Portuguese Perfect (perfeito, also known as perfeito composto) is mainly used to express situations or series of repeated situations that span from the past up to the present. As a matter of fact, PFQ material obtained from one Portuguese informant suggests that it is rather the adverb jà 'already, now' that may be grammaticalizing as the real perfect marker in this language. ${ }^{10}$

As for the Modern Greek Perfect, restrictions on its use are less drastic, but Dahl \& Hedin (this volume; cf. also Hedin 1987: 80-86) point out that in CR contexts, the Aorist can be used - just as in Bulgarian, cf. (10) above. In those contexts the Perfect focuses more on the present state of affairs and less on the past event itself than the Aorist does. Thus, the Greek Perfect is still relatively close to its resultative source - this can also be seen in the fact that it can only be formed from the Perfective ("Aorist") stem of the verb.

The gradual development of the German Perfect from a perfect into a general past tense seems to fit what Dahl (this volume) describes as a two-dimensional grammaticalization cline: both the geographical distance from the southern centre of innovation and the functional distance from the old prototypical uses of the perfect (such as CR) bear on the propensity for Perfect use (see Latzel 1974 and Thieroff, this volume on the use of the German Perfect in different contexts).

In those Romance dialects in which the perfect has become a narrative tense, it is now a perfective past, opposed to the imperfective past (Squartini \& Bertinetto, this volume). This is an instance of semantic generalization, for the CR meaning presupposes boundedness. Semantic bleaching of this kind is typical of later stages of a grammaticalization process (Hopper \& Traugott 1993: 87-93; the notion of bleaching was introduced by v.d. Gabelentz 1891: 241-242).

The change whereby the perfect of most Slavic languages has become a general past with no aspectual value of its own must at least be partly due to the fact that aspect came to be expressed by other means in Slavic. The perfect did not become a perfective past, since perfectivity vs. imperfectivity could be expressed with verbal affixes, independently of tense marking. A still stronger assumption would be that the loss of the perfect vs. narrative past distinction itself was caused by the rise of this aspect opposition, as the new Perfective, with a completive source, was able to assume resultative and CR functions.

As suggested by Dahl \& Hedin (this volume), the development from a perfect into a more general past tense "may at least partly be interpreted in terms of gradual relaxation of the requirements of current relevance". It is more difficult to say whether there is also a path from experientiality (the indefinite past function) to a general past. Such a process cannot be observed in American English, but histori- 
cal data from Slavic suggest that it is at least a typological possibility if the Slavic Perfect had already lost most of its CR functions before the other past tenses disappeared.

At any rate, it is an interesting question why a CR form tends to displace a nonCR form even when the CR distinction is lost. It should be noted that this is not what happened to the old Indo-European inflectional resultative / perfect in Greek, Latin or Germanic; in those languages, the Perfective Past or Simple Past got the upper hand, though formally incorporating parts of the old perfect morphology (as in the reduplicated Perfective Pasts of Latin, or in the $-k$ - Aorists of Modern Greek; for Germanic, see Bybee, Perkins \& Pagliuca 1994: 77-78). Thus, the morphological type of the perfect - periphrastic vs. inflectional - may have some bearing on its propensity to displace a simple past tense; the mechanism seems to be the same whereby case forms are often replaced by adpositional phrases in various languages.

In terms of grammaticalization processes, the perfect is typically a younger gram than the other (narrative) past tenses-less synthetic in its expression, more marked as to its semantic content. Its functional expansion and the concomitant semantic bleaching open a space for a new perfect to appear-an example of a grammaticalization cycle known as layering (Hopper \& Traugott 1993: 124-129). Thus, in some Slavic languages where the old perfect has become a general past tense, a new perfect is coming into existence. Such a development is observed in Czech, where the verb mít 'to have' enters with the past passive participle into constructions like Más výčištěné zuby? 'Have you brushed your teeth?' (Bybee \& Dahl 1989: 70), Mám úlohu napsanou 'I have completed my task' (Maslov 1988: 80), mít knihu rozečtenou 'to have a book half-read' (Short 1993: 487; see also Tommola, this volume, section 7).

Another possible path of evolution mentioned in connection with the perfect becoming a narrative tense is the path leading through the so-called perfect of recent past. As pointed out by Dahl (1985: 136), the development from the CR meaning into the recent-past meaning is natural because "a recent event is more likely to have a persistent result than a distant one". Sometimes a perfect acquires a hodiernal interpretation: events of the same day can be referred to by it, even in connected narrative. This is illustrated in the PFQ material from a speaker of Alicante Spanish:

\section{Alicante Spanish}

a. (PFQ: 8)

[Do you know what happened to me just an hour ago?]

Yo estaba andando en el bosque. De pronto, he pisado una culebra. Me ha mordido en la pierna. He cogido una piedra y se la he tirado a la culebra. Se ha muerto. 
b. (PFQ: 9)

[Do you know what happened to me yesterday?]

Yo estaba andando en el bosque. De pronto, pisé una culebra. Me mordió en la pierna. Cogí una piedra y se la tiré a la culebra. Se murió.

'I was walking in the forest. Suddenly I stepped on a snake. It bit me in the leg. I picked up a stone and threw it at the snake. It died.'

The italicized forms in (12a) are Perfects; in (12b), Perfective Pasts are used instead. (The questionnaire was administered by Scott Schwenter; see Schwenter 1994.)

An analogous distinction between PFQ: 8 and PFQ: 9 is made in Catalan, which is in areal contact with Alicante Spanish. The recent-past function of the perfect in Spanish, Catalan, Occitan and pre-Modern French is discussed by Comrie (1976: 60-61), Dahl (1985: 125) and Bybee, Perkins \& Pagliuca (1994: 101-102); Comrie (1976: 61) suggests that "[g]radual relaxation of the degree of recentness required for the use of the Perfect seems to have been a key part of the development of the Perfect in many Romance languages to oust the Simple Past completely". However, the study of Squartini \& Bertinetto (in this volume) on the Romance perfect does not suggest that recency has had such a central role in this development, except for a limited area in Southwest Europe, with Catalan as its centre. A more general Central and East European trend, based on areal contacts and the typological expansiveness of formally and semantically marked grams, may account for the Romance, Slavic and German development alike.

\section{Evidentiality and South Slavic perfects}

The South Slavic linguistic area consists of a series of closely connected dialects, grouped nowadays into five or six standard languages. ${ }^{11}$ The Proto-Slavic Perfect, a periphrastic formation of the 'be' type, has been preserved as a form in all of the area except for some South Macedonian dialects, but almost everywhere it has been subject to grammatical changes. However, there are two epicentres of these developments, and the respective outcomes are far from identical (Lindstedt 1993, 1994).

Starting from the Slovene territory in the northwest, the Perfect simply became a general past tense, ousting first the Imperfect, then the Aorist. These latter grams have completely disappeared in Slovene (excepting some dialects spoken mainly in Italy); in Croatian and Bosnian standard languages they have only survived as literary archaisms, apart from some expressive functions of the Aorist that have nothing to do with narration. In Serbian, the Aorist and Imperfect are more frequent, but the Perfect is already the prevalent narrative tense here, too (Savić 1991). The old system in which the Perfect is only a non-narrative tense is preserved in some Mon- 
tenegrin dialects, whose system is sometimes reflected even in modern fiction written by authors from that area (Lindstedt 1994: 39).

From the other end of the South Slavic area, a grammatical change has spread that has made the Perfect an evidential form, or rather built an evidential system out of the Perfect. Evidential, to be distinguished from mood, is, according to Trask (1993 s.v.), "a grammatical category occurring in some languages by which all statements (and sometimes other sentence types) are overtly and obligatorily marked to indicate the source of the speaker's evidence for her/his utterance" (see also Chafe \& Nichols 1986, and Willett 1988). There are no well-established terms for different types of evidentials. ${ }^{12}$ I propose the term indirective for the most widespread evidential gram type, expressing that the speaker has not witnessed the situation he or she is speaking about, but knows of it from hearsay or other kinds of indirect evidence. Other grammatical and semantic terms needed are reportative, which should be confined to the hearsay case alone, ${ }^{13}$ and inferential, referring to statements made on the basis of inference, not hearsay.

There are two major areas in Europe where grammaticalized evidentiality distinctions are common. One is the Baltic region, comprising the Baltic languages Lithuanian and Latvian and the Finnic languages Estonian and Livonian. The other area can be called the Black Sea area, as it consists of languages around this sea, though it stretches farther to Central Asia (Haarmann 1970; Dahl 1985: 149-153; Friedman 1986; Johanson 1992: 244-246). The indirectives of this area are generally regarded as having arisen due to Turkish influence during the Ottoman reign. However, the tendency to develop indirectives from various sources is typical not only of Turkish, but of the whole Turkic stock, and the area also extends from the Black Sea to regions where such Uralic languages as Komi and Udmurt, farther north, are spoken (Leinonen \& Vilkuna, this volume). It has even been called into question whether Turkish was really the primary Turkic source of the indirectives now found in the Balkans (Johanson ms.).

An interesting question is whether the two indirective areas really form a single "Eurasian isogloss" as suggested by Haarmann (1970). But as evidentiality has not been grammaticalized in East Slavic (see Tommola, this volume, section 4.6, for PFQ material), there are no data connecting the Baltic region with the east and southeast. Nothing is known about the grammatical structures of those extinct Baltic and Uralic languages of Central Russia that might have formed a bridge between the two areas.

In several languages of the Black Sea area, a resultative or a perfect has been the main diachronic source of the indirective. We can assume that the inferential meaning forms the semantic link here. Drawing inferences from the visible results of a non-witnessed event is a natural extension of resultativity or CR; it is resultativity the other way round, as it were (Comrie 1976: 108-110; Bybee, Perkins \& Pagliuca 1994: 95-96). The inference in sentence (13), for instance, can be expressed by a 
perfect even in some European languages outside the Black Sea area, though not in English:

(PFQ: 69)

[Investigating a burglary, seeing footprints beneath a window:]

The thief entered (must have entered) the house by this window.

Swedish is among the languages that can use the perfect:

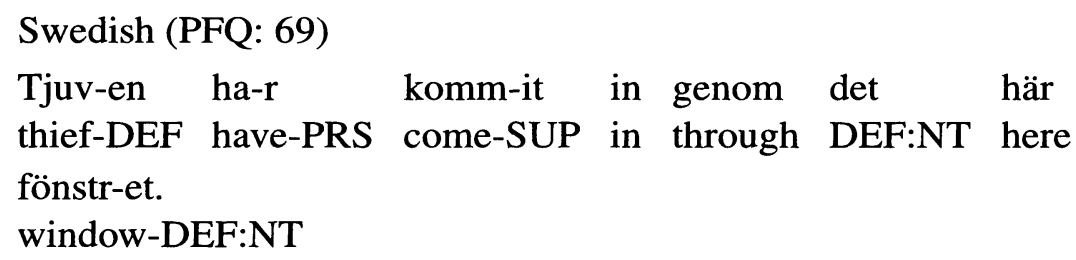

The Scandinavian inferential perfect is discussed by Haugen (1972) and, with abundant examples from Swedish, by Kinnander (1973). The use also extends to Finnish. As for the German Perfect in the same sentence (Durch dieses Fenster ist der Dieb [in das Haus] eingedrungen), its inferential value is more difficult to assess, for, as noted above, this tense has extended its use towards the preterite; but Weinrich (1964: 84-86) observes that the German Perfect is typically used in historical prose when past facts are commented on and explained, not only related in a sequence, and this can be seen as a natural extension of the inferential use.

As a further step in grammaticalization, inferentiality can be extended to the reportative meaning and other types of indirect evidence, so that a real indirective comes into existence (Bybee, Perkins \& Pagliuca 1994: 96-97, 105; cf. also Dahl 1985: 152-153, and Nedjalkov's "typological appendix" in Plungian 1988).

Another possible connection between the perfect and indirective is the fact that participles often enter into subordinate constructions expressing reported speech. Participles used as predicates in subordinate sentences seem to be the main source of indirectives in the Baltic area (Ikola 1953: 62-63; Schmalstieg 1988: 117-121), and some partially similar developments are perhaps not excluded in the Black Sea area, either. On this grammaticalization path it is the reportative meaning that forms the basis of an indirective category.

Let us now have a closer look at the South Slavic indirectives. In Bulgarian, the Perfect has given rise to an evidential form that can be characterized as an Indirective Aorist. Later, other indirective tenses have developed according to the structural model of the Indirective Aorist, such as the Indirective Imperfect (also used as the Indirective Present tense) and the Indirective Future. The distinction between the Perfect and the Indirective has been one of the most difficult questions for Bulgarian grammarians since the past century, and no definitive solution has been reached yet. (The description I gave in Lindstedt 1985 is not satisfactory, either.) 
The main descriptive problem is that the Perfect and the Indirective Aorist are not formally differentiated. The feature often mentioned in normative grammars, viz. the omission of the auxiliary in the third person of the Indirective, is not an unambiguous marker: the auxiliary is usually omitted when Indirective tenses are used in connected narrative, but this is not an absolute rule; and there are other uses of the Indirective forms that do not formally differ from the Perfect at all (Lindstedt 1993: 43-48; Lindstedt 1994: 44-47). Auxiliary drop in certain discourse types is also observed in the neighbouring Serbo-Croatian area, but it is not connected with evidentiality (Savić, this volume).

Despite the appearance of the Indirective forms, the Bulgarian Perfect has also retained its old meanings, notably the experiential (Lindstedt 1993: 49-50; 1994: 49-50). The sentence Mary has been to Paris would be translated into Bulgarian with the Perfect, and so would the sentence I have been to Paris, where the meaning is far from indirective - the speaker has certainly witnessed his or her own visits to Paris. The developmental path of the Bulgarian Perfect has clearly bifurcated: one of its two main functions is now experiential and non-narrative, the other is indirective and narrative. The linking CR function has grown weak, as noted in section 2 above; what we have here, then, is a kind of "doughnut gram" as defined by Dahl (this volume).

In Macedonian, the old 'be' perfect has acquired an indirective meaning, as in Bulgarian, but it is not so clearly polysemous owing to the appearance of a new 'have' perfect modelled on Greek and Arumanian. There is also a third, mainly resultative construction, so that 'I have come' can be expressed in three ways (the 1SG forms with a masculine subject are given):

sum došol 'I am' + past participle active, M.SG.

imam dojdeno 'I have' + past participle passive, NT.SG

sum dojden 'I am' + past participle passive, M.SG.

Friedman (1976; 1977: 52-99) and Graves (this volume) have investigated the areal and functional distribution of these grams. In Northern Macedonia the sum došol type dominates in both the perfect and indirective meaning; this is closest to the Bulgarian situation. In the southernmost part of the language area, only imam dojdeno is used. In between, in Ohrid dialects, the old perfect is only used as an indirective, and the new type imam dojdeno serves as an ordinary perfect.

As for the sum dojden type, it is still mainly a resultative proper, used in sentences like Umren $e$ 'he is dead' (lit. 'died is', PFQ: 3). However, in southwest dialects it is on its way to becoming a perfect, which is shown by the fact that even with certain transitive verbs the subject may be the agent of the action: ${ }^{14}$ 


$$
\begin{aligned}
& \text { Macedonian } \\
& \text { Jas sum jad-en-a. } \\
& \text { I be:1SG eat-PPP-F } \\
& \text { 'I've been eaten'; SW Macedonian: 'I've eaten.' }
\end{aligned}
$$

The development of the three Macedonian grams can be schematically presented as follows, depicting the synchronic situation as an on-going process, with different grams covering different stretches of the grammaticalization path:

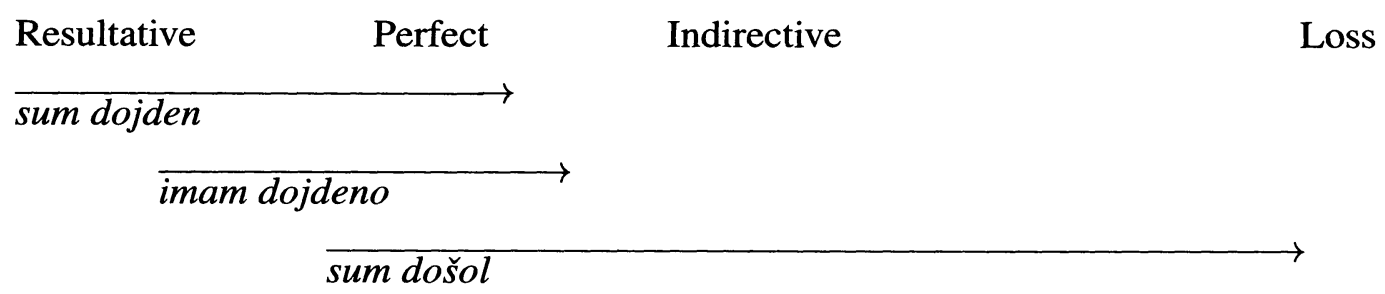

However, this diagram should not be interpreted as a prediction that the newer types of perfect are also bound to become indirectives in due course. Although this is of course possible, it is not the most probable development typologically; and areally it is not clear whether the Balkan area still favours the appearance of new indirectives, for the Turkic influence has almost vanished.

\section{The path of the perfect}

Although expressing the current relevance of a past situation is the central and prototypical meaning of the perfect, I know of no perfects that only have this function. I propose the following tentative universal: If a gram has the CR meaning, it also has at least one of the following meanings: resultative; experiential (indefinite past); inferential; reportative. If the central or sole meaning of a gram is resultative or indirective (inferential and/or reportative), it is not yet a perfect, or no longer a perfect. If the meaning of a gram has strongly shifted towards indefinite past, as in the American English Perfect or in the non-evidential branch of the Bulgarian Perfect, it is perhaps a matter of definition whether the term "perfect" should still be used. Given that CR and experientiality do not logically exclude each other, and often one and the same utterance contains elements of both, I am inclined to retain the name "perfect" for these cases. It should, however, be pointed out that the two American English speakers who completed PFQ used the Perfect in only about half of the defining items. ${ }^{15}$

Bybee, Perkins \& Pagliuca (1994: 79) list 30 "old anteriors" from their crosslinguistic sample that have developed various further uses in addition to CR. They 
also present a table of 57 "grams with anterior as their only use (young anteriors)" (1994: 64-65), but the caption is misleading: grams with other uses besides CR have been admitted to the table, if those uses (such as completive) were considered "indicative of early rather than later stages of development" (1994: 63). Moreover, experientiality or the function of anterior continuing (I've been waiting for him for an hour) was not frequently mentioned at all in the reference material used (1994: $62)$, so one cannot conclude that they are really absent from the grams of the table. Still another table (1994: 66) presents several grams that combine the resultative and "anterior" (CR) meanings.

One can reach the conclusion that current relevance is not only a function, but also a junction: grammaticalization paths from different sources, such as resultative and completive, converge here; and further paths lead from here to experiential (indefinite past), perfective past, general past, and also to indirective (cf. Bybee, Perkins \& Pagliuca 1994: 105, and also Anderson 1982: 240). Every concrete gram is only a passer-by at this junction, still having its tail in the resultative, or pushing its head towards new aspectual, temporal or evidential meanings.

\section{Notes}

1. More precisely, Part I has been completed in over thirty languages by one or more informants. The descriptive second part does not exist for all of these languages. The material will be placed on an Internet file server, possibly in the public domain if resources allow.

2. The Serbo-Croat(ian) area is the Central South Slavic dialect area between Slovene, on the one hand, and Bulgarian and Macedonian, on the other. The standard languages of this area are now called Croatian, Bosnian (see Halilovic 1991) and Serbian; they are all based on a dialect group called Neo-Štokavian.

3. It is important to comprehend the nature of this method. The crucial items in PFQ do not represent notional categories chosen a priori, because they draw upon Dahl's (1985) empirical results describing the actual clustering of grammatical categories across languages.

4. This fact need not prevent these tenses from being called Perfects in the grammars of the respective languages by force of tradition. This applies especially for languages such as Dutch and Croatian/Bosnian/Serbian, in which the old Perfect has become a narrative tense and, therefore, has ceased to be a perfect proper, yet the old narrative tense or tenses still survive as (stylistically marked) alternatives.

5. Thus, Romance perfects have mainly developed from Latin constructions involving habeo 'have' or teneo 'hold' > 'have', e.g., Navem paratam habeo 'I have a ship prepared' (Squartini \& Bertinetto in this volume; Maslov 1988: 73; cf. Bybee \& Dahl 1989: 72). Similar constructions occur in other language groups but, on the whole, 'have' perfects are a distinctively European phenomenon because "expressing 'having' by a transitive verb appears to be an areal trait of Western and Southern Europe" (Bybee \& Dahl 1989: 98, fn. 7). 
6. For the term "ascriptive", see Lyons (1977: 437-438).

7. But she also points out that the perfect often has distinct forms for the present and past tense (as in English).

8. Notice that specific time adverbials can sometimes combine with resultatives in various languages, e.g., Swedish Boken är skriven 1950 'the book was written in 1950' (lit. "is written"). Nedjalkov \& Jaxontov (1988: 54) present the German resultative Diese Stadt ist im Jahre 1794 gegründet 'this town was founded in 1794' (lit. "is founded"), but not all native speakers are happy with this example. Temporal adverbials used with resultatives typically specify the time of the resulting state, not that of the past event.

9. Unfortunately studies on "the English Perfect" do not always specify what variety of English is investigated.

10. The informant inserted já into all of the diagnostic sentences from PFQ:1 to PFQ:7, and into several other typical perfect contexts as well, but did not use the perfeito.

11. See note 2 .

12. A source of confusion is that the term "evidential" is often used as a name of an evidential gram ("the evidential in language $X$ "), just as if the imperative, for instance, were called "the mood".

13. Dahl's (1985: 149) “quotative”, though used in Amerindian studies and now adopted by Trask, is not felicitous, because to quote means 'to repeat the exact words someone has said or written'; in reportatives, only the content is repeated. Dahl now prefers the term "reportative", too (p.c.).

14. For this criterion, see Nedjalkov \& Jaxontov (1988: 23).

15. Both American English informants used the Perfect in PFQ:1, PFQ:4 and PFQ:7, one of them also in PFQ:6 (for the items, see the Appendix). An informant of British English used the Perfect in all defining items from PFQ:1 to PFQ:7 (in PFQ:3 only as a second alternative besides the stative / resultative $\mathrm{He}$ is dead).

\section{References}

Anderson, Lloyd B.

1982 "The 'Perfect' as a universal and as a language-particular category", in Paul J. Hopper (ed.), 227-264.

Bertinetto, Pier Marco \& Denis Delfitto

this volume "Aspect vs. actionality. Why they should be kept apart".

Bybee, Joan L. 1985

Morphology: A study of the relation between meaning and form. Amsterdam \& Philadelphia: Benjamins.

Bybee, Joan L. \& Östen Dahl

1989 "The creation of tense and aspect systems in the languages of the world", Studies in Language 13: 51-103.

Bybee, Joan \& Revere Perkins \& William Pagliuca

1994 The evolution of grammar: Tense, aspect, and modality in the languages of the world.

Chicago and London: University of Chicago Press.

Chafe, Wallace \& Johanna Nichols (eds.)

1986 Evidentiality: The linguistic coding of epistemology. (Advances in Discourse Processes

20.) Norwood, New Jersey: Ablex. 
Comrie, Bernard

1976 Aspect. (Cambridge Textbooks in Linguistics.) Cambridge: Cambridge University Press.

Comrie, Bernard \& Greville G. Corbett (eds.) 1993

The Slavonic Languages. London \& New York: Routledge.

Dahl, Östen

1985

Tense and aspect systems. Oxford \& New York: Basil Blackwell.

this volume "The tense-aspect systems of European languages in a typological perspective".

Dahl, Östen \& Eva Hedin

this volume "Current relevance and event reference".

Friedman, Victor A.

1976 "Dialectal synchrony and diachronic syntax: The Macedonian perfect", in Sanford B.

Steever \& al. (eds.), Papers from the parasession on diachronic syntax, Chicago Linguistic Society, 96-104.

1977 The grammatical categories of the Macedonian indicative. Columbus, Ohio: Slavica.

1986 "Evidentiality in the Balkans: Bulgarian, Macedonian, and Albanian", in Chafe \& Nichols (eds.), 168-187.

Gabelentz, Georg von der

1891 Die Sprachwissenschaft. Ihre Aufgaben, Methoden und bisherigen Ergebnisse. [Linguistics: Its tasks, methods and present findings.] Leipzig: Weigel.

Graves, Nina

this volume "Macedonian - a Language with Three Perfects?"

Greenberg, Joseph H.

1978 "Diachrony, synchrony, and language universals", in Greenberg (ed.), 61-91.

Greenberg, Joseph H. (ed.)

1978 Universals of human language, I: Method \& theory. Stanford, California: Stanford University Press.

Haarmann, Harald

1970 Die indirekte Erlebnisform als grammatische Kategorie. Eine eurasische Isoglosse.

[The indirect evidential form as a grammatical category: An Eurasian isogloss.] (Veröffentlichungen der Societas Uralo-Altaica 2.) Wiesbaden: Otto Harrassowitz.

Halilovic, Senahid

1991 Bosanski jezik. [The Bosnian language.] (Biblioteka Bosanski krug.) Sarajevo: Biblioteka Ključanin.

Haugen, Einar 1972

"The inferential perfect in Scandinavian: a problem for contrastive linguistics", The Canadian Journal of Linguistics 17: 132-139.

Hedin, Eva

1987 On the use of the perfect and the pluperfect in Modern Greek. (Acta Universitatis Stockholmiensis, Studia Graeca Stockholmiensia 6.) Stockholm: Almqvist \& Wiksell.

Hopper, Paul J. (ed.)

1982 Tense-aspect: Between semantics and pragmatics. Amsterdam: Benjamins.

Hopper, Paul J. \& Elizabeth Closs Traugott

1993 Grammaticalization. (Cambridge Textbooks in Linguistics.) Cambridge: Cambridge University Press.

Ikola, Osmo 1953

Viron ja liivin modus obliquuksen historiaa. [On the history of the modus obliquus in Estonian and Livonian.] Helsinki: Suomalaisen Kirjallisuuden Seura. (Suomi 106: 4; with a German summary: "Zur Geschichte des estnischen und livischen Modus obliquus".) 
Johanson, Lars 1992

Strukturelle Faktoren in türkischen Sprachkontakten. [Structural factors in contacts with Turkic languages.] (Sitzungsberichte der Wissenschaftlichen Gesellschaft an der Johann Wolfgang Goethe-Universität. Frankfurt am Main, XXIX, 5.) Stuttgart: Franz Steiner.

manuscript "Zum Kontakteinfluß türkischer Indirektive". [On the contact influence of the Turkic indirective.]

Kinnander, Bengt 1973

"Perfektum i 'sekundär' användning" [On the perfect in a 'secondary' use.], Nysvenska studier 53: 127-172.

Latzel, Sigbert 1974

"Zum Gebrauch der deutschen Vergangenheitstempora. Zwei Studien" [On the use of the German past tenses. Two studies.], in Hermann Gelhaus \& Sigbert Latzel, Studien zum Tempusgebrauch in Deutschen. (Institut für deutsche Sprache, Forschungsberichte, 15.) Mannheim, 169-348.

Leinonen, Marja \& Maria Vilkuna

this volume "Past tenses in Permian languages".

LÈS = Lingvističeskij ènciklopedičeskij slovar' [Encyclopedic dictionary of linguistics]

1990 Moskva: Sovetskaja ènciklopedija.

Lindstedt, Jouko 1983

"The past is present: notes on the perfect tense", in Fred Karlsson (ed.), Papers from the Seventh Scandinavian Conference of Linguistics, I. (University of Helsinki, Department of General Linguistics, Publications 9.) Helsinki. 246-259.

1985 On the semantics of tense and aspect in Bulgarian. (Slavica Helsingiensia 4.) Helsinki.

1993 "Za razvitieto na južnoslavjanskija perfekt" [On the development of the South Slavic perfect], Studia Slavica Finlandensia 10: 31-54.

1994 "On the development of the South Slavonic Perfect", in Three papers on the perfect, 32-53. (EUROTYP Working Papers VI: 5).

1995 "Understanding perfectivity - understanding bounds", in Pier Marco Bertinetto, Valentina Bianchi, Östen Dahl \& Mario Squartini (eds.), Temporal reference, aspect and actionality, vol. 2: Typological perspectives. Torino: Rosenber \& Sellier. 95-103.

Lyons, John

1977 Semantics 1-2. Cambridge: Cambridge University Press.

McCoard, Robert W.

1978 The English perfect: Tense-choice and pragmatic inferences. (North-Holland Linguistic Series 38.) Amsterdam: North Holland.

Maslov, Jurij S.

1988 "Resultative, perfect, and aspect", in Nedjalkov (ed.), 63-85.

Maslov, Ju. S.

$1990 \quad$ "Perfekt" [Perfect], in LÈS, p. 372.

Nedjalkov, Vladimir P. (ed.)

1988 Typology of resultative constructions. (Typological Studies in Language 12.) Amsterdam \& Philadelphia: John Benjamins. [An enlarged translation of Tipologija rezul'tativnyx konstrukcij (rezul'tativ, stativ, passiv, perfekt). Leningrad 1983: Nauka.]

Nedjalkov, Vladimir P. \& Sergej Je. Jaxontov

1988 "The typology of resultative constructions", in Nedjalkov (ed.), 3-62.

Plungian, Vladimir A.

1988 "Resultative and apparent evidential in Dogon", in Nedjalkov (ed.), 481-493. (With a

“Typological appendix” by V. P. Nedjalkov.) 
Savić, Svenka 1991

"Pragmatični aspekti vremena u naraciji u srpskohrvatskom standardnom jeziku" [Pragmatic aspects of tenses in naratives in the Serbo-Croatian standard language], Godišnjak Filozofskog fakulteta u Novom Sadu 20: 149-155.

this volume "Discourse features of the truncated perfect in spoken Serbo-Croatian". Schmalstieg, William R.

1988 A Lithuanian historical syntax. Columbus, Ohio: Slavica.

Schwenter, Scott A.

1994 "The grammaticalization of an anterior in progress: Evidence from a peninsular Spanish

Short, David

1993 "Czech", in Comrie \& Corbett (eds.), 455-532.

Squartini, Mario \& Pier Marco Bertinetto

this volume "The simple and compound past in Romance languages".

Thieroff, Rolf

this volume "On the areal distribution of tense-aspect categories in Europe".

Tommola, Hannu

this volume "On the perfect in North Slavic".

Trask, R. L.

1993 A dictionary of grammatical terms in linguistics. London \& New York: Routledge.

Trubinskij, Valentin I.

1988 "Resultative, passive, and perfect in Russian dialects", in Nedjalkov (ed.), 389-409.

Weinrich, Harald

1964 Tempus: Besprochene und erzählte Welt. Stuttgart: W. Kohlhammer.

Willett, Thomas

1988 "A cross-linguistic survey of the grammaticization of evidentiality", Studies in Language 12: 51-97. 